\title{
Penguatan Kelembagaan Desa dalam Musyawarah Rencana Pembangunan Desa (Musrenbangdes Tahun 2021) di Kabupaten Kampar Provinsi Riau
}

\author{
Eka Eka ${ }^{1}$, Widia Astuti ${ }^{2}$ and Aguswan Aguswan ${ }^{3}$ \\ 1,2,3 Fakultas Ilmu Administrasi, Universitas Lancang Kuning, Indonesia \\ eka1983@unilak.ac.id
}

\begin{abstract}
Abstrak
Penelitian yang dilaksanakan di kabupaten Kampar, Provinsi Riau, dimana fokus penelitian mengkaji tentang penguatan kelembagaan desa dalam mempersiapkan pelaksanaan musrenbang desa yang berdaya guna dan berhasil guna. Hasil dari kegiatan musrenbang adalah penetapan prioritas pembangunan desa yang harus sesuai dengan Rencana Pembangunan Desa (RPJMDes 6 tahun dan RKP 1 tahun), sebagai kerangka strategi pembangunan desa yang di inginkan. Pendekatan penelitian yang digunakan adalah pendekatan kualitatif dengan mendeskriptifkan dan menafsirkan proses perencanaan desa yang dilaksanakan oleh Pemerintah Desa dan unsur-unsur yang terlibat dalam kegiatan pembangunan Desa. Musrenbang Desa adalah forum tahunan yang dilaksanakan mulai dari desa, kecamatan dan berakhir di kabupaten/kota. Untuk itu desa harus siap dalam menyusun rencana pembangunan desa yang baik. Perencanaan desa tersusun dan tersistematis membutuhkan organisasi dan kelembagaan yang kuat yaitu mampu menjalankan tugas pokok dan fungsinya. Tugas dan fungsinya merumuskan perencanaan desa, melaksanakan pembangunan desa, mengawasi pembangunan dan mengevaluasi hasil pembangunan desa. Penguatan kelembagaan desa dalam penyusunan perencanaan desa harus memilki data dan informasi yang lengkap dan akurat yang dapat mempermudah petugas perencana dalam menyusun dan menyiapkan rencana pembangunan desa secara efektif. Data dan informasi yang dimaksud dalam mendukung penyusunan perencanaan pembangunan desa meliputi: (1) Penyelenggaraan pemerintahan desa, (2) Organisasi dan tatalaksana pemerintahan desa, (3) Keuangan desa, (4) Profil desa dan (5) Informasi lain terkait dengan penyelenggaraan pemerintahan desa dan pemberdayaan masyarakat. Hasil penelitian yang diperoleh bahwa organisasi dan kelembagaan desa yaitu Pemerintah Desa, Permusyawaratan Desa kurang memiliki pengetahuan dan pemahaman dalam menjalankan tugas, pokok serta fungsi organisasi secara baik dan benar. Dan hal ini yang menyebabkan tujuan dan sasaran pembangunan tidak diperkuat dengan pemahaman aparatur dalam berorganisasi.
\end{abstract}

Kata kunci: Penguatan; organisasi; musrenbang desa

\section{Pendahuluan}

Secara hirarki desa merupakan pemerintahan paling bawah yang berhadapan langsung dengan warganya dalam memberikan pelayanan, pembangunan dan pemberdayaan masyarakat. Oleh karen itu peran aktif kepala desa dan perangkatnya mampu menyelenggarakan pemerintahan desa yang kuat, mandiri dan professional dalam memenuhi kebutuhan dan kepentingan masyarakat desa. Desa disebut sebagai wilayah otonom memiliki kewenangan dalam penyelenggaran rumah tangga desa. Adapun kewenangan penuh diberikan yaitu kewenangan di bidang penyelenggaraan
Pemerintahan Desa, pelaksanaan Pembangunan Desa, pembinaan kemasyarakatan Desa, dan pemberdayaan masyarakat desa berdasarkan prakarsa masyarakat, hak asal usul, dan adat istiadat Desa.

Desa menurut UU No. 06 tahun 2014 adalah kesatuan masyarakat hukum yang memiliki batas wilayah yang berwenang untuk mengatur dan mengurus urusan pemerintahan, kepentingan masyarakat setempat berdasarkan prakarsa masyarakat, hak asal usul, dan/atau hak tradisional yang diakui dan dihormati dalam sistem pemerintahan Negara Kesatuan Republik Indonesia. Oleh karena itu Pemerintahan 
Desa merupakan penyelenggaraan urusan pemerintahan dan kepentingan masyarakat setempat dalam sistem pemerintahan Negara Kesatuan Republik Indonesia

Selanjutnya pada pasal 94, UU. No. 06 2014 disebutkan bahwa (1) Desa mendayagunakan lembaga kemasyarakatan Desa yang ada dalam membantu pelaksanaan fungsi penyelenggaraan Pemerintahan Desa, pelaksanaan pembangunan Desa, pembinaan kemasyarakatan Desa, dan pemberdayaan masyarakat Desa. (2) Lembaga kemasyarakatan Desa sebagaimana dimaksud pada ayat (1) merupakan wadah partisipasi masyarakat Desa sebagai mitra Pemerintah Desa. (3) Lembaga kemasyarakatan Desa bertugas melakukan pemberdayaan masyarakat Desa, ikut serta merencanakan dan melaksanakan pembangunan, serta meningkatkan pelayanan masyarakat Desa. (4) Pelaksanaan program dan kegiatan yang bersumber dari Pemerintah, Pemerintah Daerah Provinsi, Pemerintah Daerah Kabupaten/Kota, dan lembaga non-Pemerintah wajib memberdayakan dan mendayagunakan lembaga kemasyarakatan yang sudah ada di desa.

Sehubungan dengan hal di atas desa harus dapat mendayakan fungsi kelembagaan yang ada di desa tersebut. Keberadaan kelembagaan desa tentunya dapat membantu pemerintah desa dan masyarakatnya dalam mengupayakan mempersiapkan program-program pembangunan yang sesuai dengan perencanaan pembangunan yang di tujukan. Perencanaan dan pelaksanaan pembangunan desa harus di sesuaikan dengan dokumen Rencana Pembangunan jangka menengah desa (RPJM Desa) dan Rencana Kerja Pemerintah Desa (RKP Desa). dalam merujuk pada dokumen perencanaan desa, maka dalam pelaksanaan pembangunan desa diperlukan penyusunan perencanaan desa yang tersistem, terintegrasi sesuai dengan aspirasi dan kebutuhan masyarakat.

Kabupaten Kampar merupakan salah satu dari 12 kabupaten/kota di Provinsi Riau.
Kabupaten Kampar terdiri dari 12 kecamatan dengan jumlah desa sebanyak 250 desa dan kelurahan. Dikecamatan Tambang Kabupaten Kampar terdapat 21 desa, yang salah satunya adalah desa Kuapan. Perencanaan desa di susun dan diperkuat dalam kegiatan musyawarah rencana pembangunan desa (Musrenbangdes) dan lembaga desa seperti pemerintahan desa beserta lembaga pemberdayaan masyarakat (LPM) memiliki tugas dan tanggungjawab dalam perencanaan desa yang ditetapkan. Sehubungan itu keberadaan desa kuapan dalam menyelenggarakan pemerintahan, pembangunan dan pelayanan masyarakat tidak terlepas dari upaya desa dalam menyusun rencana program dan kegiatan pembangunan. Program dan kegiatan pembangunan tentunya terlebih dahulu di susun dengan baik dan selanjutnya rencana dan program kegiatan tersebut diperkuat dalam forum musrenbang desa. luaran dari musrenbang desa adalah Penetapan prioritas pembangunan desa.

Untuk mencapai tujuan pembangunan desa dan kesejahteraan masyarakat desa, maka diperlukan penguatan lembaga desa yang kuat dalam menyelengarakan tugas pokok dan fungsi yang telah di emban. Lembaga-lembaga desa terdiri dari pemerintahan desa, badan musyawarah desa, organisasi perempuan (PKK), LPM, RT/RW dan organisasi kepemudaan (karang taruna). Tugas pokok dan fungsi masing-masing lembaga seharusnya dapat berfungsi dengan baik. Namun kondisi yang ada bahwa lembaga-lembaga desa masih belum dapat berfungsi dengan baik. Hal ini disebabkan tingkat pengetahuan dan pemahaman berorganisasi masih rendah, rendahnya partisipasi masyarakat dan permasalahan komplik sosial yang sering terjadi ditengah masyarakat Desa.

\subsection{Rumusan Masalah}

Berdasarkan masalah, maka penulis mengangkat permasalahan yang dibahas adalah apakah Penguatan Kelembagaan desa dalam Musrenbang Desa (musrenbangdes) 
Eka Eka, Widia Astuti and Aguswan Aguswan / Penguatan Kelembagaan Desa dalam Musyawarah

Rencana Pembangunan Desa (Musrenbangdes Tahun 2021) di Kabupaten Kampar Provinsi Riau

dapat dilaksanakan di Desa Kuapan Kecamatan Tambang kabupaten Kampar.

\section{Tinjauan Pustaka}

\subsection{Pembangunan}

Pembangunan secara sederhana di artikan sebagai suatu perubahan tingkat kesejahteraan secara sengaja dan terukur. Agar perubahan tingkat kesejahteraan dapat dilakukan secara terukur diperlukan perencanaan. UU Nomor 25 tahun 2004 tentan Sistem perencanaan pembangunan Nasional (selanjutnya disingkat UU SPN) saat ini. UU tersebut menjadi landasan formal aktivitas lembaga perencanaan pembangunan nasional, yaitu Badan Perencanaan Pembangunan Nasional (Bapppenas) dalam melakukan melakukan penyusunan rencana pembangunan nasional.

Nugroho (2011) memberikan makna perencanaan dalam arti yang luas dan sempit. Dalam arti luas perencanaan merupakan upaya manusia meminimalkan ketidakpastian. Dan perencanaan ideal adalah langkah-langkah yang dilakukan manusia agar kepastian semakin dekat dalam kehidupan manusia. Kemudian perencanaan dalam arti sempit, sesungguhnya drivat dari kemampuan Foresight itu. Yaitu kemampuan mengukur (measuring). Inti perencanaan yang ideal sesungguhnya adalah mengukur. Persoalannya tidak semua "sesuatu "itu bersifat materi, sehingga sifatnya "tersembunyi", sehingga sulit di ukur. Di sinilah sesungghunya tugas perencana yaitu mendefenisikan "sesuatu yang tersembunyi" menjadi terukur, sehingga menjadi nyata. Sebagai contoh paling sederhana mendefeniskan "bahagia". Bahagia barang kali sulit di ukur dibandingkan dengan "sejahtera". Inilah tugas perencana. Bagaimana perencana menuntaskan tugasnya.

Berdasarkan kerangka hukum yang ada perencanaan pembangunan pada semua tingkatan pemerintah harus menggunakan pendekatan partisipatif. Perencanaan partisipastif menggunakan pendekatan dua arah: dari atas kebawah (Top Down) dan dari bawah ke atas (Bottom up). suatu forum yang dipakai untuk menyelenggarakan perencanaan partisipasi dikenal dengan istilah teknis Musrembang (musyawarah perencanaan pembangunan). Musrembang dimulai dari satuan pemerintahan paling bawah yaitu tingkat Desa/kelurahan kemudian secara hirakis ke atas yaitu tingkat kecamatan, tingkat kabupaten/kota, provinsi dan terakhir tingkat pusat.

Untuk menghasilkan dokumen perencanaan partisipatif, pemerintah Kabupaten kota perlu melakukan langkahlangkah yang terencana, terarah, daan terfokus. Bappeda sebagai dapur perencanaan pembangunan Pemerintah daerah merancang langkah-langkah kegiatan untuk menghsilkan dokumen tersebut. Langkah-langkah kegiatan tersebut mulai dari tahap persiapan, penyiapan bahan, penentuan jadwal, fasilitasi untuk pembahasan, formulasi, finalisasi dan proses legislasi.

Musrembang di kabupaten/Kota dapat dikelompokan dalam tiga jenis

1. Musrembang Desa/kelurahan (dilaksanakan pada bulan Januari)

2. Musrembang kecamatan (dilaksanakan pada bulan Februari)

3. Musrembang kabupaten/kota (dilaksanakan pada bulan Maret).

Tugas pemerintahan desa/kelurahan dalam menyusun perencanaan pembangunan Desa/kelurahan adalah melaksanakan musyawarah Perencanaan pembangunan Desa/kelurahan (Musrenbang Desa/kelurahan) dengan melibatkan secara aktif seluruh masyarakat desa secara benar. Tujuan Musrembang Desa/kelurahan antara lain:

1. Menampung aspirasi dan menetapkan prioritas kebutuhan masyarakat yang diperoleh dari musyawarah perencanaan pada tingkat di bawahnya.

2. Menetapkan prioritas kegiatan desa yang akan dibiayai melalui alokasi Dana Desa yang berasal dari APBD kabupaten/Kota maupun sumber pendanaan lainnya. 
3. Menetapkan prioritas kegiatan yang akan di ajukan untuk dibahas pada musrembang kecamatan.

Kemudian Masukan Musrembang Desa/kelurahan yang dipersiapkan oleh Sekretaris Desa/ kelurahan berupa:

1. Daftar permasalahan desa, seperti peta kerawanan kemiskinan dan pengangguran.

2. Dokumen rencana pembangunan jangka menengah (RPJM) desa/kelurahan. Hasil evaluasi pelaksanaan pembangunan desa/kelurahan tahun sebelumnya.

3. Daftar prioritas masalah di bawah desa/kelurahan dan kelompokkelompok masayarakat, seperti kelompok petani, nelayan dan sebagainya.

Keluaran (hasil) musrembang Desa kelurahan adalah dokumen-dokumen yang berisikan:

1. Prioritas kegiatan pembangunan skala desa/kelurahan yang akan di danai oleh alokasi dana desa dan atau swadaya.

2. Prioritas kegiatan pembangunan yang akan dilaksanakan melalui SKPD yang dilengkapi dengan kode desa/kelurahan dan kecamatan dan akan masih dibahas pada forum musrembang kecamatan.

3. Berita acara musrembang desa/kelurahan (Nurkholis, 2008: 97).

UU No. 06 tahun 2014 pasal 1 menyebutkan Desa adalah desa dan desa adat atau yang disebut dengan nama lain, selanjutnya disebut Desa, adalah kesatuan masyarakat hukum yang memiliki batas wilayah yang berwenang untuk mengatur dan mengurus urusan pemerintahan, kepentingan masyarakat setempat berdasarkan prakarsa masyarakat, hak asal usul, dan/atau hak tradisional yang diakui dan dihormati dalam sistem pemerintahan Negara Kesatuan Republik Indonesia.

Fungsi lembaga kemasyarakatan Desa antara lain (i) Penampungan dan penyaluran aspirasi masyarakat, (ii) Penanaman dan pemupukan rasa persatuan dan kesatuan masyarakat dalam kerangka memperkokoh Negara Kesatuan Republik Indonesia, (iii) Peningkatan kualitas dan percepatan pelayanan pemerintahan pada masyarakat, (iv) Penyusunan rencana, pelaksana dan pengelola pembangunan secara partisipatif, (v) Penggerak prakasa swadaya gotongroyong masyarakat, (vi) Pendayagunaan dan pengembangan potensi sumber daya serta keserasian lingkungan hidup, (vii) Pengembangan kreatifitas, pencegahan kenakalan, penyalah gunaan obat terlarang di remaja, (viii) Pemberdayaan dan peningkatan kesejahteraan keluarga, (ix) pemberdayaan dan perlindungan hak politik masyarakat, (x) pendukung komunikasi informasi, sosialisasi antar pemerintah dan masyarakat.

UU Nomor 32 Tahun 2004, Pasal 97 PP No 72 tahun 2005, UU No 23 tahun 2014 tentang Pemerintahan daerah dan UU Nomor 6 Tahun 2014 tentang Desa memberikan penguatan fungsi kelembagaan desa yang berada pemerintah daeerah. Jenis Lembaga Kemasyarakatan Desa/Kelurahan, yaitu Rukun Tetangga (RT), Rukun Warga (RW), Pembinaan Kesejahteraan Keluarga (PKK), Karang Taruna (KARTAR) dan Lembaga Pemberdayaan Masyarakat (LPMD/K) atau yang disebut dengan nama lain, lembaga adat dan lembaga kemasyarakatan lainnya sesuai kebutuhan.

Lembaga

kemasyarakatan

Desa/Kelurahan bertugas melakukan pemberdayaan masyarakat Desa/Kelurahan, ikut serta merencanakan dan melaksanakan pembangunan, serta meningkatkan pelayanan masyarakat desa. Sebagai mitra Pemerintah Desa/Kelurahan, tugas Lembaga Kemasyarakatan meliputi 1) Menyusun rencana pembangunan secara partisipatif; 2) Melaksanakan, mengendalikan, memanfaatkan, memelihara dan mengembangkan pembangunan secara partisipatif; 3) Menggerakkan dan mengembangkan partisipasi, gotong-royong dan swadaya masyarakat; 4) Menumbuhkembangkan kondisi dinamis masyarakat dalam rangka pemberdayaan masyarakat;

Penguatan organisasi dan kelembagaan desa yang berlangsung disetiap desa adalah dengan memperkuat pelaksanaan 
Rencana Pembangunan Desa (Musrenbangdes Tahun 2021) di Kabupaten Kampar Provinsi Riau

musrembang desa yang dilaksanakan setiap tahunnya. Untuk memperkuat kelembagaan desa dalam persiapan musyawarah rencana pembangunan desa, maka diperlukan penyusunan perencanaan desa yang baik. Penyusunan perencanaan pembangunan desa harus pada data dan informasi yang akurat dan dapat dipertanggung jawabkan. Data dan informasi yang dibutuhkan oleh organisasi dan kelembagaan desa dalam memperkuat musrembang desa yaitu: Penyelenggaraan Pemerintahan desa, Organisasi dan tatalaksana pemerintahan desa, Keuangan desa, Profil desa dan Informasi lain terkait dengan penyelenggaraan pemerintahan desa dan pemberdayaan masyarakat. (Nurcholis, 2011:108).

\section{Metode}

Penelitian dilaksanakan di kabupaten Kampar dengan fokus penelitian menkaji tentang penguatan kelembagaan desa dalam musyawarah rencana pembangunan desa (musrenbang Desa). pendekatan penelitian yang digunakan pendekatan kualitatif dengan mendeskripsikan hasil yang diperoleh pada obyek atau fokus penelitian. Melalui wawancara dengan stakholders desa (Kepala desa, Ketua LPM, BPD dan Tokoh masyarakat) untuk mendapatkan menggali imformasi-informasi yang relevan dan dokumen-dokumen yang dapat mendukung hasil penelitian

\section{Hasil dan Pembahasan}

Penguatan kelembagaan desa dalam penyusunan perencanaan desa harus memilki data dan informasi yang lengkap dan akurat yang dapat mempermudah petugas perencana dalam menyusun dan menyiapkan rencana pembangunan desa secara efektif. Data dan informasi yang dimaksud dalam mendukung penyusunan perencanaan pembangunan desa meliputi:

1. Penyelenggaraan Pemerintahan desa,

2. Organisasi dan tatalaksana pemerintahan desa,

3. Keuangan desa,

\section{Profil desa dan.}

5. Informasi lain terkait dengan penyelenggaraan pemerintahan desa dan pemberdayaan masyarakat.

Kelima data dan informasi tersebut sangat bermamfaat dalam mendukung penyusunan perencanaan pembangunan desa baik yang dilaksanakan pada Musyawarah Rencana Pembangunan Desa mapun dalam musyawarah desa (musdes) yang dilaksanakan setiap tahunnya. Hasil penelitian yang telah dilaksanakan dengan melibatkan beberapa informent penelitian baik yang berasal dari aparatur desa maupun dari tokoh desa kuapan kecamatan Tambang kabupaten Kampar, maka hasil penelitian menyebutkan bahwa perencanaan pembangunan desa yang dibahas setiap tahunnya dalam memperkuat musrembang desa dan penetapan prioritas pembangunan desa kurang efektif (berdaya guna), sebagai akibat dari fungsi - fungsi lembaga desa yang kurang dapat berfungsi dengan baik, sehingga penyusunan perencanaan desa yang dibahas pada musyawarah desa (musdes) ataupun musyawarah perencanaan pembangunan desa (musrenbangdes) kurang sesuai dengan rencana dan program yang pembangunan desa.

Perencanaan pembangunan desa adalah proses tahapan kegiatan yang diselenggarakan oleh Pemerintah Desa dengan melibatkan badan Permusyawaratan desa dan unsur-unsur masyarakat secara partisipatif guna pemamfaatan dan pengalokasian sumber daya desa dalam rangka mencapai tujuan pembangunan desa. lebih lanjut bahwa pembangunan partisipatif adalah sebuah sistem pengelolaan pembangunan di desa dan kawasan pedesaan yang dikoordinasikan oleh Kepala Desa dengan mengedepankan kebersamaan, kekeluargaan dan kegotong royongan guna mewujudkan perdamaian dan keadilan sosial.

Dalam menyusun sebuah rencana yang baik mestinya didukung oleh sejumlah data dan informasi yang memadai agar rencana yang disusun dapat memecahkan masalah 
yang ditemui atau di alami masayarakat desa melalui potensi yang di milikinya. Permasalahannya adalah jenis data apa yang dibutuhkan, sumber informasi, jenis dan kedalaman data, bagaimana memperoleh data dan informasi yang di butuhkan.

Penyusunan

Perencanaan pembangunan Desa membutuhkan data dan informasi yang lengkap dan akurat sehingga memudahkan kepala kepala desa bersama perangkatnya untuk menyusun perencanaan desa dengan baik. Seluruh unsur-unsur desa yang terlibat dalam penyusunan perencanaan desa baik harus memahami hal-hal pokok tentang data dan informasi yang menjadi bagian terpenting dalam pembuatan rencana desa yang baik. Berikut di kemukakan dimensi- dimensi penguatan kelembagaan desa dalam penyusun perencanaan desa yang saling melengkapi kebutuhan dalam penyusunan perencanaan desa:

\subsection{Penyelenggaraan Pemerintahan Desa}

Pemerintah Desa menyusun perencanaan pembangunan desa sesuai dengan keenangannya dengan mengacu pada perencanaan pembangunan kabupaten/kota. Pembangunan desa mencakup bidang penyelenggaraan pemerintahan desa, pelaksanaan pembangunan desa dan pemberdayaan masyarakat. Penyusunan perencanaan pembangunan desa dilakukan secara berjangka yang meliputi:

1. Rencana Pembangunan jangka menengah desa (RPJMdes) untuk jangka waktu 6 (enam) tahun dan.

2. Rencana Pembangunan tahunan desa atau yang disebut Rencana Kerja Pemerintah Desa (RKP Desa) merupakan penjabaran RPJM desa untuk jangka waku satu tahun.

Rancangan RPJM desa yang di susun harus memuat visi dan misi kepala desa, arah kebijakan pembangunan desa, serta rencana kegiatan yang meliputi penyelenggaraan pemerintahan desa, pelaksanaan pembangunan desa, pembinaan kemasyarakat desa dan pemberdayaan masyarakat desa. Kepala desa dengan visi \& misi yang canangkannya selama enam tahun dan setiap tahun pelaksanaan dilaksanakan penyeusunan perencananan desa dalam bentuk rencana pembangunan jangka menengah desa RPJM desa dan rencana kerja pemerintahan (RKP Desa). Dalam pelaksanaannya kegiatan RPJM Desa dan RKP Desa di perkuat dalam kegiatan musyawarah rencana pembangunan desa (MusrembangDes) dan Musyawarah Desa (Musdes). Artinya kepala desa bersama badan permusyawaratan desa (BPD) menetapkan perencanaan pembangunan desa secara bersama-sama sebagai pedoman dalam pelaksanaan pembangunan desa di Desa Kuapan Kecamatan Tambang.

Bidang penyelenggaraan pemerintahan desa antara lain penetapan dan penegasan batas-batas desa, pendataan desa, penyusunan tata ruang desa, penyelenggaraan musyawarah desa, pengelolaan informasi desa, penyelenggaraan perencanaan desa, penyelenggaraan evaluasi tingkat perkembangan desa, penyelenggaraan kerja sama antar desa, pembangunan sarana dan prasarana kantor dan kegiatan lainnya sesuai dengan kondisi desa.

Dari data yang diperoleh tentang penyelenggaraan pemerintahan desa di desa kuapan kecamatan tambang yang menjadi kendala adalah batas desa yang belum akurat dan bahkan menimbulkan komplik atau pertentangan di saat warga masyarakat melakukan pembuatan atau penguruan surat keterangan tanah (SKT). Hal yang demikian dapat menimbulkan tumpang tindih kepemilikan tanah di arael perbatasan desa yang belum jelas. Dalam hal ini diperlukan kerjasama antar desa untuk melakukan penetapan tapal batas secara jelas, sehinga tidak menjadi polemic antara warga masyarakat dan memudahkan dalam perencanaan pembangunan desa yang dibahas dalam pelaksanaan musyawarah rencana pembangunan desa (MusrenbangDesa). 
Eka Eka, Widia Astuti and Aguswan Aguswan / Penguatan Kelembagaan Desa dalam Musyawarah

Rencana Pembangunan Desa (Musrenbangdes Tahun 2021) di Kabupaten Kampar Provinsi Riau

\subsection{Organisasi dan tatalaksana desa}

Organisasi dan tatalaksana desa merupakan kemampuan sumberdaya organisasi dan sumber daya manusia dalam menyelenggarakan tugas pokok dan fungsi Pemerintahan Desa yang efektif dan efisien. Data dan informasi mengenai organisasi dan tatalaksana desa dijadikan bahan dan informasi untuk memperkuat penyusunan perencanaan pembangunan desa. Penyusunan perencanaan Pembangunan desa yang lengkap dapat dijadikan masukan dalam kegiatan Musyawarah rencana pembangunan desa. Ketersedian data dan informasi organisasi tata laksana desa mencakup pada aspek tata kelola manajemen Desa, sarana dan prasarana, SDM aparatur.

Penata kelola manajemen desa merupakan tugas dan tanggung jawab kepala desa untuk memperkuat tugas dan fungsi pemerintahan desa. kegiatan merencanakan, melaksanakan, mengawasi dan mengevaluasi pembangunan desa harus tersusun dan terintegrasi yang merupakan satu kesatuan memperkuat kedudukan dan fungsi organisasi desa. Untuk sumber daya desa (aparatur desa) perlu memiliki kemampuan dalam menyelenggarakan program dan kegiatan sebagai maana yang telah disusun dalam tugas dan fungsi Pemerintahan Desa.

Sumber daya organisasi yang tersedia dan di dukung dengan sumber daya manusia yang berkualitas dapat memperkuat sistem pengelolaan pemerintahan desa yang dilaksanakan oleh kepala desa bersama perangkatnya. Data dan informasi mengenai organisasi dan tata laksana dapat dijadikan bahan dan masukan untuk mendukung penyusunan perencanaan pembangunan desa. berdasarakan kondisi yang terjadi di desa Kuapan bahwa organisasi dan tatalaksa kurang mampu dalam mneyelenggarakan tugas dan fumgsinya. Hal ini terlihat dari kurang cakapnya pegawai desa dalam mengerjakan kegiatan-kegiatan pemerintahan desa. untuk itu perlunya penata kelolaan pegawai dengan memberikan pendidikan dan pelatihan formal dan informal yang dapat membantu penyelenggaraan pemerintahan desa dan pembangunan desa.

\subsection{Keuangan Desa}

Keuangan desa adalah semua hak dan kewajiban dalam rangka peyelenggaraan pemerintahan desa yang dapat dinilai dengan uang, termasuk didalamnya segala bentuk kekayaan yang berhubungan dengan hak dan kewajiban desa. Keuangan desa berasal dari pendapatan asli desa, APBD dan APBN. Penyelenggaraan urusan pemerintahan desa yang menjadi kewenangan desa didanai dari APBDesa, bantuan Pemerintah pusat dan bantuan Pemerintahan daerah.

Pemerintah desa wajib mengelolah keuangan desa secara transparan, akuntabel, partisipatif serta dilakukan dengan tertib dan disiplin. Transparan artinya dikelola secara terbuka; akuntabel artinya dipertanggungjawabkan secara legal dan partisipatif artinya melibatkan masyarakat dalam penyusunannya. Keungan desa harus dilakukan dengan kaidah sistem akuntansi keuangan pemerintahan.

Pemerintah desa setiap tahun wajib menyusun APBDesa. APBDesa merupakan pembiayaan terhadap program pembangunan tahunan yang diselenggarakan oleh Pemerintahan desa. Program pembangunan tahunan desa diturunkan dari program pembangunan jangka menengah desa (enam tahun) yang disebut dengan rencan pembangunan jangka menengah desa (RPJMDesa). RPJMDesa merupakan penjabaran visi dan misi dari kepala Desa terpilih. Setelah RPJMDesa ditetapkan dengan peraturan desa bersama Badan Permusyawaratan Desa (BPD) menyusun rencana kerja pemerintahan Desa (RKP Desa) yang merupakan penjabaran dari RPJM Desa.

Sehubungan dengan hal di atas, bahwa pengelolaan keuangan desa yang dilaksanakan oleh aparatur desa yang ditunjuk oleh kepala Desa harus memahami mekanisme perencanaan, pelaksanaan dan serta pertanggungjawaban APBDesa dan 
pelaporannya. Dari kondisi yang ada bahwa petugas administrasi dan ketatausahaan keuangan desa kurang mampu menyelenggarakan administrasi dengan tatakelola keuangan yang baik, sehingga penyusunan perencanaan desa dan penatapan prioritas pembangunan desa kurang didukung dengan kemampuan dan keterampilan pegawai dalam pengelolaan keuangan desa.

\subsection{Profil Desa}

Profil desa merupakan gambaran umum desa yang menjelaskan kondisi desa secara keseluruhan. Profil Desa berisikan tentang Data keluarga, data potensi desa dan data perkembangan desa. Keseluruhan data yang tersedia dapat dijadikan bahan dan masukan dalam pelaksanaan musyawarah rencana pembangunan desa (musrembangDes). Profil desa dapat memberikan arahan dan gambaran tentang kondisi desa baik dalam peneyelenggaran pemerintahan, pembangunan dan pelayanan kepada masyarakat. Profil desa yang tersusun sesuai dengan keadaan dan kondisi desa yang sesungguhnya dapat membantu semua pihak untuk mendapatkan informasi-informasi desa, dan pada khususnya dapat membantu aparatur desa di dalam kegatan penyusunan perencanaan pembangunan desa yang lebih baik.

Data keluarga sangat penting untuk di tampilkan dalam profil desa. data keluarga harus menjelaskan secara keadaan penduduk, jumlah jiwa dan jumlah kepala keluarga dalam suatu desa. disamping itu dapat menggambarkan jumlah penduduk berdasarkan pendidikan, pekerjaan, agama, suku dan adat yang berlangsung pada suatu desa. dalam hal ini keadaan profil data keluarga masih dalam kategori kurang lengkap.

Selanjutnya profil tentang potensi desa harus disediakan oleh pemerintah desa. potensi-potensi desa harus ada dan dikembangkan. Perlunya data potensi ini sangat membantu desa dalam mendukung program-program pembangunan desa. seperti potensi wisata, pertanian, kerajinan desa, pasar dan sebagainya. Keseluruhan ini memerlukan data-data untuk dikembangkan. Apabila potensi desa dan masalah yang dihadapi menjadi bahasan bersama bagi pemerintahan desa dalam menyusun dan merecanakan pembangunan desa. khsusunya memperkuat pembahasan dalam musyawarah rencana pembangunan desa dan penetapan prioritas pembangunan desa.

Profil desa juga berisikan perkembangan desa menjadi desa yang kuat dan mandiri. Desa harus dapat membangun kehidupan masyarakatnya untuk maju dan berkembanagan. Hal ini perkembangan desa dapat dilihat dari status desa swadaya, swakarya dan swasembada. Untuk desa kuapan sudah termasuk desa swasemba yang telah meningkat program pembangunan pertanian dan perkebunan, khsusnya kebun karet dan sawit yang menjadi komoditi pendapatan umum masyarakat.

\subsection{Informasi Pemerintahan dan Pemberdayaan Masyarakat Desa}

Menyusun rencana yang baik semestinya di dukung oleh sejumlah data dan informasi yang memadai agar rencana yang disusun dapat memecahkan masalah yang ditemui atau di alami oleh masyarakat desa melalui potensi yang di milikinya. Permasalahannya adalah jenis data apa yang di butuhkan, sumber informasi, jenis dan kedalaman data, bagaimana cara memperoleh data dan informasi yang dibutuhkan.

Untuk itu pemerintah desa harus mampu menyediakan data dan informasi yang dapat berguna bagi kepentingan masyarakat maupun pihak-pihak yang membutuhkan informasi tentang desa. Penyelenggara desa sudah sepatutnya untuk menyediakan berbagai informasi-informasi yang dapat menginformasi perkembangan desa. informasi tersebut sangat berguna baik untuk pemerintahan maupun untuk kelompok-kelompok lain yang membutuhkannya.

Informasi-informasi yang disediakan desa tentunya disampaikan tentang pembangunan desa, penyelenggaraan 
Rencana Pembangunan Desa (Musrenbangdes Tahun 2021) di Kabupaten Kampar Provinsi Riau

pemerintahan desa, pembinaan desa, evaluasi pembangunan desa dan informasi umum (public) yang dapat diperoleh oleh masyarakat desa secara mudah. Pemerintah desa harus mampu memberikan segala bentuk informasi yang dapat diketahui oleh masyarakat. Masyarakat dapat memberikan saran dan kritik terhadap masalah -masalah desa.

Oleh karena itu pemerintah desa perlu juga memberdayakan masyarakatya. Pemberdayaan masyarakat desa adalah upaya mengembangkan kemandirian dan kesejahteraan masyarakat dengan meningkatkan pengetahuan, sikap, keterampilan, perilaku, kemampuan, kesadaran, serta memamfaatkan sumber daya melalui penatapan kebijakan, program, kegiatan dan pendampingan yang sesuai dengan esiensi masalah dan prioritas kebutuhan masyarakat.

\section{Kesimpulan}

Kepala desa sebagai pimpinan tertinggi di desa maka kepala desa berkewajiban untuk mewujudkan visi \& misinya yang diperkuat dalam kegiatan rencana kerja pemerintah desa setiap tahunnya yang dilaksanakan dalam Musrembangdesa.

Penguatan kelembagaan desa adalah sangat penting untuk dilaksanakan. Upaya yang dilakukan dengan memberikan pengetahuan dan ketrampilan kepada aparatur pelaksana desa. Organisasi atau kelembagaan desa memiliki tanggung jawab untuk merencanakan, melaksanakan, mengawasi dan mengevaluasi pembangunan desa. Pembangunan desa yang dilaksanakan adalah hasil penggodokan dai musyawarah pembangunan desa (musrenbangdes), dengan luar musrenbangDes adalah penetapan prioritas pembangunan Desa yang di danai oleh Pemerintahan kabupaten/kota.

Untuk mencapai tujuan daan luaran musrenbng Desa yang baik dan tepat sasaran, maka organisasi desa harus kuat dan mampu dalam menyelenggarakan pemerintahan, pembangunan, pelayanan dan pemberdayaan masyarakat. Untuk itu pemerintahan desa sebagai organisasi formal desa harus mampu menyusun perencanaan desa dan penetapan prioritas pembangunan desa sesuai dengan Rencana Pembangunan jangka Menengah Desa (RPMJdes) dan di tuangkan ke dalam Rencana Kerja Pemerintahan Desa (RKP) desa. kemampuan organisasi desa dalam merencanakan pembangunan desa dan penatapan prioritas pembangunan desa adalah dengan menyediakan data dan informasi yang dapat mendukung dalam penyusunan dan penetapan perencanaan pembangunan pedesaan.

Ada beberapa faktor penghambat yang mempengaruhi lemahnya organisasi desa dalam penyusunan perencanaan dan penetapan prioritas pembangunan desa pada saat pelaksanaan Musrenbang desa berlansgung, diantaranya: Sumber daya aparatur desa yang kurang memiliki pengetahuan, keterampilan dan keahlian (skill) dalam menyelenggaraan Pemerintahan Desa; Tata kelola dan tata laksana desa yang belum memahami pengetahuan tentang organisasi dan manajemen yang baik; Perencanaan, pelaksanaan, pemamfaatan dan evaluasi pembangunan desa yang kurang efektif ; Pembinaan dan pengawasan terhadap pembangunan desa yang kurang berjalan; Program pemberdayaan dan pendampingan belum efektif dan kurang terintegrasi dengan penyelenggaraan pemerintahan daerah dan desa.

\section{Daftar Pustaka}

Aguswan, A. (2017). Sistem Informasi Pelayanan Public Dikecamatan Kampar Timur Kabupaten Kampar. Jurnal Niara, 10(1), 34-41. Aguswan, S., \& Nurfeni, M. S. (2018). Model Perencanaan Partisipatif Pembangunan Desa. Jakad Media Publishing.

Creswel, J. (2010). Reserach Design. Yogyakarta: Pustaka Pelajar. 
Himpunan Petunjuk Pelaksanaan Desa/ Kelurahan. (2008). Fokusindo, Bandung.

Kartikawanto, I. (2013). Perencanaan pembangunan partisipatif kelurahan dan desa. Journal of Public Administration, 14(1).

Nugroho, R., \& Wrihatnolo, R. (2011). Manajemen perencanaan pembangunan. Kompas Gramedia, Jakarta.

Nurcholis, H. (2009). Perencanaan Partisipatif Pemerintah Daerah. Grasindo.

Nurcholis, H. (2011). Pertumbuhan \& penyelenggaraan pemerintahan desa. Erlangga.

Peraturan Pelaksana Pemerintahan daerah, 2006, Eko Jaya Jakarta.

Rancangan Awal RPJMD Propinsi Riau 2014 - 2019, Pekanbaru, Bappeda Provinsi Riau, Pekanbaru.

Rencana Strategi 2014-2019, Badan perencanaan pembangunan daerah (BAPPEDA) Propinsi Riau, Pekanbaru.
Suhendra, K., \& Kadmasasmita, A. D. (2006). Peranan Birokrasi dalam Pemberdayaan Masyarakat. Alfabeta.

The Law No.6 of 2014 About Village. Surabaya: Rona Publishing Press. 